\title{
Pengurangan Dosis Pupuk pada Produksi Sawi Hijau Organik dengan Pergiliran Tanaman Jagung dan Kedelai
}

\author{
Reduction of Manure Rate for Brassica iuncea \\ Production with Crop Rotation of Corn and Soybean
}

\author{
Ari Kurniawati' ${ }^{1}$, Maya Melati2 ${ }^{2 *}$, Sandra Arifin Aziz ${ }^{2}$, dan Purwono ${ }^{2}$ \\ ${ }^{1}$ Program Studi Agronomi dan Hortikultura, Sekolah Pascasarjana, Institut Pertanian Bogor \\ ${ }^{2}$ Departemen Agronomi dan Hortikultura, Fakultas Pertanian, Institut Pertanian Bogor \\ (Bogor Agricultural University), Jl. Meranti, Kampus IPB Darmaga, Bogor 16680, Indonesia
}

Diterima 12 Agustus 2016/Disetujui 4 April 2017

\begin{abstract}
The application of organic fertilizer and crop rotation are combination of cultivation system integrally to preserve land fertility. This study aimed to determine the effect of crop residues produced in the first season to reduce organic fertilizer rate for mustard greens cultivation in the second season. The experiment was conducted at IPB organic farm, Cikarawang, Darmaga in April until June 2015. The first season was the first experiment conducted separately for soybean and corn to study different manure types for both crops which the rate of each manure was 20 ton ha-1 for soybean and 25 ton ha ${ }^{-1}$ for corn. Soybean and corn residues were used in the following season on mustard green cultivation. The experimental design was split plot design with crop residues as main plot, and combination of manure types (chicken, cow, goat) and rates $(0,10$ ton ha ${ }^{-1}$ ) as sub plot. Data were analyzed using variance. Means were statistically compared with Tukey test at $\alpha<0.05$ level. The results showed that the soybean and corn residues can be used as nutrient sources for mustard greens cultivation. The application of manure was not necessary for mustard greens cultivation if soybean or corn residues were added in the second season and there was residues from manure in the first season.
\end{abstract}

Keywords: chicken manure, cow manure, crop residue, goat manure

\section{ABSTRAK}

Pemupukan organik dan penerapan sistem pergiliran tanaman merupakan kombinasi teknik budidaya secara terpadu untuk menjaga kesuburan lahan. Penelitian ini bertujuan untuk mengetahui pengaruh residu tanaman yang dihasilkan pada musim tanam pertama (MT 1) terhadap pengurangan dosis pupuk organik pada penanaman sawi hijau di musim tanam kedua (MT 2). Percobaan dilakukan di Kebun Percobaan organik IPB Cikarawang, Darmaga, Bogor pada April sampai Juni 2015. Musim tanam pertama dirancang sebagai percobaan pertama yang dilakukan terpisah pada tanaman kedelai dan jagung untuk menguji berbagai jenis pupuk kandang dengan masing-masing dosis yang digunakan adalah 20 ton ha-1 untuk kedelai dan 25 ton ha ${ }^{-1}$ untuk jagung. Residu kedua tanaman tersebut digunakan pada percobaan kedua untuk tanaman sawi hijau. Rancangan yang digunakan adalah split plot design dengan petak utama, yaitu jenis residu tanaman dan anak petaknya adalah kombinasi jenis pupuk kandang (ayam, sapi, dan kambing) dengan dosisnya (0 dan 10 ton ha- ${ }^{-1}$ ). Data dianalisis menggunakan sidik ragam dan diuji lanjut menggunakan uji BNJ pada taraf kesalahan 5\%. Hasil percobaan menunjukkan bahwa residu tanaman kedelai dan jagung dapat digunakan sebagai tambahan unsur hara pada penanaman sawi hijau. Tidak perlu penambahan dosis pupuk kandang pada budidaya sawi hijau di MT 2 jika pada MT 1 diberikan pupuk kandang sebesar 20 ton ha ${ }^{-1}$ dan pengembalian residu tanaman dari MT 1.

Kata kunci: kotoran ayam, kotoran kambing, kotoran sapi, residu tanaman

* Penulis untuk korespondensi.e-mail: maya_melati05@yahoo.com 


\section{PENDAHULUAN}

Penerapan budidaya organik dapat mengurangi dampak pencemaran lingkungan karena aplikasinya tidak menggunakan bahan kimia, melainkan menggunakan bahan organik yang berasal dari limbah pertanian dan peternakan. Penggunaan pupuk organik dalam dosis yang cukup tinggi mampu menyediakan unsur hara untuk tanaman. Selain itu, pemupukan organik memiliki keuntungan lain, seperti dapat memperbaiki struktur tanah (Trisnadewi et al., 2012) dan menurut Kresnatita et al. (2013), pupuk organik dapat mengikat unsur hara yang mudah hilang serta membantu dalam penyediaan unsur hara tanah, sehingga efisiensi pemupukan menjadi lebih tinggi.

Beberapa kendala yang muncul pada budidaya organik justru meningkatkan biaya produksi dengan produktivitas yang rendah. Suplai hara yang diberikan oleh pupuk organik sangat rendah, sehingga budidaya secara organik membutuhkan penggunaan pupuk organik dalam jumlah besar (Oryschak et al., 2011). Selain itu, serangan organisme pengganggu tanaman (OPT) masih tinggi karena teknik pengendalian pada pertanian organik skala luas belum maksimal. Oleh karena itu, dibutuhkan solusi budidaya sayuran secara organik yang efektif dan efisien.

Pemupukan organik yang berasal dari limbah pertanian dan peternakan serta penerapan sistem pergiliran tanaman merupakan teknik kombinasi yang dianggap dapat menjaga kesuburan lahan serta termasuk salah satu cara pengendalian OPT secara terpadu. Pergiliran tanaman merupakan salah satu pola tanam dengan melakukan penanaman tanaman yang berlainan jenis dalam beberapa musim tanam dengan tujuan untuk memutus siklus hama dan menjaga kesuburan tanah. Pemilihan jenis tanaman yang digilirkan sebaiknya berasal dari famili yang berbeda, seperti penanaman legum pada musim tanam pertama, kemudian dilanjutkan dengan penanaman sayuran daun.

Penambahan residu tanaman dan pupuk kandang pada sistem pergiliran tanaman berpotensi sebagai sumber hara karena dapat meningkatkan kandungan bahan organik tanah (Abbasi et al., 2015). Menurut Mohammad et al. (2012), penggunaan residu tanaman yang dikombinasikan dengan rotasi tanaman legum dapat meningkatkan produksi biji dan brangkasan gandum jika dibandingkan dengan rotasi tanaman non legum. Menurut Blair et al. (2006), penerapan rotasi tanaman di Australia dengan memasukkan tanaman legum juga berpotensi melestarikan kesuburan tanah.

Sawi hijau (Brassica juncea) merupakan sayuran daun yang pertumbuhannya akan terpacu jika tanah banyak mengandung bahan organik dan kelembaban yang cukup (Yulia et al., 2011). Penambahan bahan organik pada penanaman sawi hijau berpotensi untuk menggantikan penggunaan pupuk kimia sintetis (Agustina et al., 2012). Menurut Yulia et al. (2011), residu bahan organik dapat meningkatkan produksi sawi hijau pada musim tanam kedua. Oleh karena itu, penelitian ini bertujuan untuk mengetahui pengaruh bahan organik dari sisa tanaman pada musim tanam pertama terhadap pengurangan dosis pupuk organik di musim tanam kedua, sehingga dapat meningkatkan produktivitas tanaman dengan memanfaatkan sistem agroekologi yang sesuai.

\section{BAHAN DAN METODE}

Percobaan dilaksanakan di Kebun Percobaan organik IPB Cikarawang, Darmaga, Bogor yang memiliki ketinggian 250 mdpl pada April sampai Juni 2015. Percobaan ini dilakukan pada musim tanam kedua, yaitu setelah pertanaman jagung dan kedelai yang telah dibudidayakan secara organik untuk menguji tiga jenis pupuk kandang, yaitu pupuk kandang ayam, sapi, dan kambing dengan masing-masing dosis 20 ton $\mathrm{ha}^{-1}$ untuk kedelai dan 25 ton $\mathrm{ha}^{-1}$ untuk jagung. Residu panen kedua tanaman tersebut digunakan pada budidaya tanaman sawi hijau di musim tanam kedua untuk mengetahui pengaruh residu pupuk kandang dan residu tanaman jagung serta kedelai terhadap pertumbuhan dan produksi tanaman sawi hijau.

Rancangan yang digunakan adalah split plot design dengan dua faktor. Petak utamanya adalah residu jenis tanaman yang terdiri atas dua taraf, yaitu residu tanaman jagung dan kedelai. Anak petaknya adalah kombinasi jenis pupuk kandang (ayam, sapi, dan kambing) dengan dosisnya ( 0 dan 10 ton $\mathrm{ha}^{-1}$ ) yang terdiri atas tujuh taraf, sehingga kombinasi dua faktor tersebut berjumlah 14 perlakuan (Tabel 1). Selain itu, perlakuan kontrol organik tanpa residu tanaman dan konvensional juga dilakukan secara terpisah dari rancangan utama dengan masing-masing pengulangan sebanyak tiga kali.

Sawi ditanam pada petakan berukuran $1.5 \mathrm{~m} \times 2 \mathrm{~m}$ dengan jarak tanam $20 \mathrm{~cm}$ x $20 \mathrm{~cm}$. Aplikasi residu tanaman dengan cara ditebar di atas permukaan lahan setelah dilakukan pencacahan pada residu tanaman dengan ukuran 7-15 cm. Lahan kemudian diberakan selama dua bulan dan diolah kembali serta diberi perlakuan pemupukan pada saat dua minggu sebelum tanam secara alur. Pemeliharaan tanaman, meliputi penyiraman setiap hari dan pemberian pestisida nabati yang berasal dari ekstrak bawang putih dan bawang merah. Sawi dipanen pada umur 7 MST. Variabel pengamatan terdiri atas, komponen pertumbuhan dan hasil tanaman sawi, serta kadar hara NPK pada pupuk dan jaringan daun. Data dianalisis menggunakan sidik ragam dan diuji lanjut menggunakan uji BNJ pada taraf kesalahan 5\%. Selain itu, untuk membandingkan masing-masing perlakuan kontrol dengan rancangan utama digunakan uji $t$-student.

\section{HASIL DAN PEMBAHASAN}

\section{Pengaruh Pengurangan Dosis Pupuk Kandang dan Penambahan Residu Tanaman terhadap Pertumbuhan dan Hasil Tanaman Sawi Hijau}

Tidak ada pengaruh interaksi antara jenis residu tanaman dan kombinasi berbagai jenis dan dosis pupuk kandang terhadap variabel pertumbuhan dan produksi tanaman sawi. Jenis residu tanaman jagung dan kedelai yang diaplikasikan sebagai tambahan bahan organik juga tidak memberikan pengaruh yang nyata terhadap pertumbuhan dan hasil tanaman sawi (Tabel 2 dan 3). 
Tabel 1. Rincian perlakuan pemberian pupuk pada petak penanaman sawi hijau di musim tanam kedua

\begin{tabular}{|c|c|c|c|c|c|}
\hline \multirow{3}{*}{ Perlakuan } & \multicolumn{2}{|c|}{ Jenis residu tanaman } & \multicolumn{3}{|c|}{ Pupuk kandang } \\
\hline & Kedelai & Jagung & Ayam & Sapi & Kambing \\
\hline & \multicolumn{5}{|c|}{ 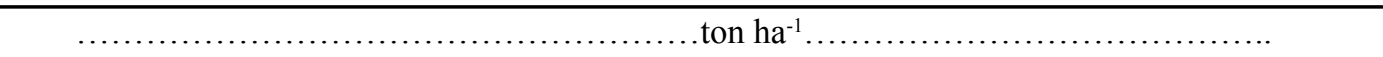 } \\
\hline 1 & 8.63 & - & 10 & - & - \\
\hline 2 & 8.63 & - & 0 ( ada residu MT1) & - & - \\
\hline 3 & 8.63 & - & - & 10 & - \\
\hline 4 & 8.63 & - & - & 0 ( ada residu MT1) & - \\
\hline 5 & 8.63 & - & - & - & 10 \\
\hline 6 & 8.63 & - & - & - & $0($ ada residu MT1) \\
\hline 7 & 8.63 & - & - & - & - \\
\hline 8 & - & 8.63 & 10 & - & - \\
\hline 9 & - & 8.63 & 0 ( ada residu MT1) & - & - \\
\hline 10 & - & 8.63 & - & 10 & - \\
\hline 11 & - & 8.63 & - & 0 ( ada residu MT1) & - \\
\hline 12 & - & 8.63 & - & - & 10 \\
\hline 13 & - & 8.63 & - & - & 0 ( ada residu MT1) \\
\hline 14 & - & 8.63 & - & - & - \\
\hline $\left.15^{1}\right)$ & - & - & 10 & - & - \\
\hline $\left.16^{1}\right)$ & - & - & - & 10 & - \\
\hline $\left.17^{1}\right)$ & - & - & - & - & 10 \\
\hline $\left.18^{2}\right)$ & & 2 ton pup & indang ayam per hekta & $+100 \mathrm{~kg}$ NPK per hekt & \\
\hline
\end{tabular}

Keterangan: ${ }^{1)}$ Merupakan perlakuan pembanding organik tanpa residu tanaman. ${ }^{2}$ Merupakan perlakuan pembanding anorganik. MT $1=$ musim tanam pertama, Penentuan dosis 8.63 ton ha ${ }^{-1}$ residu tanaman berdasarkan rataan masing-masing bobot residu jagung dan kedelai dari perlakuan berbagai jenis pupuk kandang pada MT 1 yang telah dikonversi dari per petak menjadi per hektar. Penentuan dosis 10 ton ha ${ }^{-1}$ berdasarkan setengah dari dosis MT 1, yaitu 25 ton ha ${ }^{-1}$ untuk jagung dan 20 ton ha ${ }^{-1}$ untuk kedelai. Selain pupuk kandang, pada MT 1 juga ditambahkan 4 ton ha-1 Tithonia diversifolia dan 1 ton ha ${ }^{-1}$ arang sekam pada masingmasing pupuk kandang yang digunakan

Meskipun secara statistik tidak nyata, residu tanaman kedelai menyebabkan nilai peubah yang diamati lebih tinggi daripada yang mendapat residu tanaman jagung. Hal ini disebabkan sisa tanaman kedelai memberikan sumbangan hara $\mathrm{N}$ sebesar hampir 3 kali lipat dibandingkan tanaman jagung (Tabel 4). Hal ini juga didukung oleh penelitian Rahman et al. (2013) yang menunjukkan bahwa residu tanaman kecipir (legum) dapat menghasilkan biomassa dan akumulasi kadar $\mathrm{N}$ yang lebih tinggi pada tanaman padi. Hasil penelitian Supriyadi (2008) juga menunjukkan bahwa residu tanaman yang berasal dari famili legum dapat dimanfaatkan sebagai sumber hijauan yang akan meningkatkan C-total dan non labil. Menurut Liang et al. (2014), peningkatan laju dekomposisi C-organik tanah ini disebabkan oleh tingginya kandungan nitrogen pada tanaman legum yang berasal dari fiksasi nitrogen oleh bakteri rhizobium.

Sumbangan hara dari pupuk organik dan residu tanaman dapat digunakan sebagai perkiraan sumbangan hara potensial, namun kondisi tersebut tidak mempertimbangkan kemungkinan kehilangan hara, kecepatan dekomposisi setiap jenis pupuk, dan perbedaan waktu ketersediaan hara ke dalam tanah (Ramadhani, 2011). Jika hanya berdasarkan sumbangan hara dari penambahan pupuk kandang ayam dan kambing sebesar 10 ton ha $^{-1}$ serta residu tanaman (Tabel 4), jumlah NPK telah mencukupi kebutuhan hara tanaman sawi. Berdasarkan IFA (1992), serapan $\mathrm{N}_{2} \mathrm{P}_{2} \mathrm{O}_{5}$, dan $\mathrm{K}_{2} \mathrm{O}$ pada tanaman Brassica oleraceae (kubis) berturut-turut adalah 121, 32, dan $106 \mathrm{~kg} \mathrm{ha}^{-1}$ untuk produksi sebesar 29 ton $\mathrm{ha}^{-1}$.

Jumlah sumbangan hara dari pupuk kandang kambing memiliki nilai tertinggi dibandingkan dengan pupuk kandang ayam (Tabel 4), namun penambahan dosis pupuk kandang ayam sebesar 10 ton ha' (setengah dari dosis MT 1) memberikan nilai tertinggi pada tinggi tanaman dan bobot sawi per hektar (Tabel 2 dan 3). Hal ini disebabkan oleh pupuk kandang kambing memiliki bentuk kotoran yang menyulitkan dalam pelepasan hara, sehingga proses penyediaan hara lebih lama jika dibandingkan dengan pupuk kandang ayam. Tanaman sawi merupakan tanaman semusim yang memiliki umur pendek, sehingga membutuhkan hara tersedia yang lebih cepat agar dapat diserap untuk pertumbuhan tanaman.

Meskipun pengaruh pupuk kandang hanya nyata pada tinggi tanaman, namun terdapat kemiripan pengaruh pupuk terhadap jumlah dan luas daun. Pengaruh pupuk kandang ayam dan kambing lebih baik jika dibandingkan dengan 
Tabel 2. Pengaruh berbagai teknik budidaya terhadap pertumbuhan tanaman sawi

\begin{tabular}{|c|c|c|c|}
\hline Perlakuan & Tinggi tanaman $(\mathrm{cm})$ & Jumlah daun (helai) & Luas daun $\left(\mathrm{cm}^{2}\right)$ \\
\hline \multicolumn{4}{|l|}{ Jenis residu } \\
\hline Kedelai & 36.1 & 12 & 1407.1 \\
\hline Jagung & 32.9 & 10 & 1090.6 \\
\hline \multicolumn{4}{|c|}{ jenis dan dosis pupuk kandang (ton $\mathrm{ha}^{-1}$ ) } \\
\hline P. ayam (10) & $37.5 \mathrm{a}$ & 12 & 1452.8 \\
\hline P. ayam $(0)$ & $36.4 \mathrm{ab}$ & 11 & 1306.0 \\
\hline P. sapi (10) & $34.8 \mathrm{ab}$ & 10 & 1407.7 \\
\hline P. sapi (0) & $32.7 b$ & 9 & 1062.8 \\
\hline P. kambing (10) & $34.0 \mathrm{ab}$ & 12 & 1364.8 \\
\hline P. kambing (0) & $33.4 \mathrm{ab}$ & 11 & 1146.5 \\
\hline Tanpa pupuk & $31.9 b$ & 11 & 1001.4 \\
\hline Rata-rata & $34.5 x y$ & $11 x$ & $1248.9 x y$ \\
\hline P. ayam/sapi/kambing (10) & 30.7 & 8 & 978.2 \\
\hline Konvensional & 28.9 & 9 & 807.4 \\
\hline
\end{tabular}

Keterangan: Angka yang diikuti huruf kecil yang sama tidak menunjukkan perbedaan yang nyata pada taraf 5\%. Huruf $\mathrm{x}$ artinya berbeda nyata pada uji $\mathrm{t}$ dengan perlakuan pembanding pupuk kandang ayam/sapi/kambing tanpa residu tanaman. Huruf y artinya berbeda nyata pada uji t dengan perlakuan pembanding konvensional

pupuk kandang sapi. Selanjutnya, jika membandingkan antar dosis, terlihat bahwa nilai ketiga peubah ini relatif lebih rendah jika tidak dilakukan pemupukan pada musim tanam kedua (Tabel 2).
Tidak ada perbedaan yang nyata antara penambahan dan tanpa penambahan dosis pupuk untuk masing-masing jenis pupuk kandang. Namun, jika dibandingkan antar jenis pupuk kandang, penambahan dosis pupuk kandang

Tabel 3. Pengaruh berbagai teknik budidaya terhadap hasil tanaman sawi

\begin{tabular}{|c|c|c|c|c|c|}
\hline Perlakuan & $\begin{array}{l}\text { Bobot segar } \\
\text { tajuk per } \\
\text { tanaman }(\mathrm{g})\end{array}$ & $\begin{array}{l}\text { Bobot segar } \\
\text { akar per } \\
\text { tanaman }(\mathrm{g})\end{array}$ & $\begin{array}{c}\text { Persentase } \\
\text { tanaman } \\
\text { panen }(\%)\end{array}$ & $\begin{array}{l}\text { Bobot sawi } \\
\text { (ton ha-1) }\end{array}$ & $\begin{array}{c}\text { Kadar air } \\
(\%)\end{array}$ \\
\hline \multicolumn{6}{|l|}{ Jenis residu } \\
\hline Kedelai & 98.6 & 4.3 & 76 & 23.9 & 94.97 \\
\hline Jagung & 85.0 & 4.5 & 74 & 20.6 & 94.61 \\
\hline \multicolumn{6}{|c|}{ Jenis dan dosis pupuk kandang (ton $\mathrm{ha}^{-1)}$} \\
\hline P. ayam (10) & 116.0 & 4.8 & 65 & $27.1 \mathrm{a}$ & 95.57 \\
\hline P. ayam $(0)$ & 116.5 & 5.1 & 72 & $25.0 \mathrm{ab}$ & 95.46 \\
\hline P. sapi (10) & 70.5 & 4.0 & 76 & $21.2 \mathrm{abc}$ & 93.62 \\
\hline P. sapi (0) & 73.4 & 4.0 & 86 & $20.2 b c$ & 94.55 \\
\hline P. kambing (10) & 101.0 & 4.6 & 73 & $24.3 \mathrm{ab}$ & 94.71 \\
\hline P. kambing (0) & 86.0 & 4.2 & 72 & $20.3 b c$ & 95.06 \\
\hline Tanpa pupuk & 79.6 & 4.2 & 80 & $17.5 \mathrm{c}$ & 94.54 \\
\hline Rata-rata & $91.8 x y$ & $4.4 x y$ & $75 x y$ & $22.2 x y$ & 94.79 \\
\hline P. ayam/sapi/kambing (10) & 54.2 & 3.4 & 66 & $12.7 \mathrm{z}$ & $95.31 \mathrm{z}$ \\
\hline Konvensional & 50.7 & 2.9 & 50 & 6.9 & 93.12 \\
\hline
\end{tabular}

Keterangan: Angka yang diikuti huruf kecil yang sama tidak menunjukkan perbedaan yang nyata pada taraf $5 \%$. Huruf $\mathrm{x}$ artinya berbeda nyata pada uji t dengan perlakuan pembanding pupuk kandang ayam/sapi/kambing tanpa residu tanaman. Huruf y artinya berbeda nyata pada uji $t$ dengan perlakuan pembanding konvensional. Huruf $\mathrm{z}$ artinya berbeda nyata pada uji $\mathrm{t}$ antara perlakuan pupuk kandang ayam/sapi/kambing tanpa residu tanaman dengan perlakuan konvensional 
Tabel 4. Sumbangan hara pupuk organik yang ditambahkan pada percobaan sawi hijau organik

\begin{tabular}{|c|c|c|c|c|}
\hline \multirow{2}{*}{ Jenis pupuk organik } & \multicolumn{3}{|c|}{ Sumbangan hara $\left(\mathrm{kg} \mathrm{ha}^{-1}\right)$} & \multirow{2}{*}{ Kadar air $(\%)$} \\
\hline & $\mathrm{N}$ & $\mathrm{P}$ & $\mathrm{K}$ & \\
\hline Residu tanaman kedelai (8.63 ton $\left.\mathrm{ha}^{-1}\right)$ & 166 & 15 & 50 & 5.78 \\
\hline Residu tanaman jagung (8.63 ton $\left.\mathrm{ha}^{-1}\right)$ & 56 & 6 & 40 & 8.64 \\
\hline Pupuk ayam (10 ton $\left.\mathrm{ha}^{-1}\right)$ & 143 & 54 & 44 & 55.39 \\
\hline Pupuk sapi (10 ton $\left.\mathrm{ha}^{-1}\right)$ & 160 & 8 & 8 & 62.56 \\
\hline Pupuk kambing (10 ton $\mathrm{ha}^{-1}$ ) & 204 & 58 & 59 & 54.48 \\
\hline Pupuk NPK Phonska (konvensional) & 44 & 14 & 15 & - \\
\hline
\end{tabular}

Keterangan: Sumbangan hara tidak termasuk residu pupuk organik dari MT 1. Perhitungan sumbangan hara berasal dari perkalian antara jumlah pupuk organik yang digunakan (ton atau $\mathrm{kg}$ ) dan kadar unsur hara dalam pupuk (\%)

ayam sebesar 10 ton ha $^{-1}$ memberikan pengaruh yang lebih baik pada bobot sawi per hektar jika dibandingkan dengan tanpa penambahan pupuk kandang sapi (Tabel 3). Hal ini disebabkan oleh residu pupuk kandang sapi pada MT 1 lebih sedikit dibandingkan pupuk kandang lainnya. Hal ini juga dapat ditunjukkan pada sumbangan hara yang diberikan oleh pupuk kandang sapi di Tabel 4.

Penambahan dosis pupuk kandang sapi sebesar 10 ton ha $^{-1}$ secara statistik mampu memberikan pertumbuhan dan hasil yang sama dengan penggunaan pupuk kandang ayam, tetapi perbedaan produksi mencapai sekitar 6 ton ha ${ }^{-1}$ lebih tinggi jika menggunakan pupuk kandang ayam. Hal ini juga dipengaruhi oleh kadar air tanaman sawi yang diberi perlakuan pupuk kandang ayam lebih tinggi daripada pupuk kandang lainnya, sehingga menghasilkan bobot segar tajuk per tanaman yang juga lebih tinggi (Tabel 3 ).

Bobot segar tajuk per tanaman yang lebih tinggi pada penggunaan pupuk kandang ayam menyebabkan bobot sawi per hektar juga lebih tinggi, walaupun persentase tanaman yang dipanen lebih rendah jika dibandingkan dengan pupuk kandang sapi. Menurut Susanto (2002), penggunaan pupuk kandang ayam dalam dosis tinggi akan menyebabkan kematian benih dan bibit karena pupuk kandang ayam mengandung senyawa allelopati yang berfungsi sebagai herbisida.

Tabel 5. Pengaruh residu tanaman dan jenis serta dosis pupuk kandang terhadap kadar hara pada jaringan daun tanaman sawi

\begin{tabular}{llll}
\hline \multirow{2}{*}{ Perlakuan } & \multicolumn{3}{c}{ Kadar hara pada jaringan daun (\%) } \\
\cline { 2 - 4 } & $\mathrm{N}$ & $\mathrm{P}$ & $\mathrm{K}$ \\
\hline Jenis residu & 3.76 & 0.52 & 3.37 \\
Kedelai & 3.58 & 0.53 & 3.43 \\
Jagung & & & \\
Jenis dan dosis pupuk kandang $\left(\right.$ ton $\left.^{-1}{ }^{-1}\right)$ & 3.86 & 0.57 & $3.72 \mathrm{a}$ \\
P. ayam (10) & 3.68 & 0.53 & $3.44 \mathrm{abc}$ \\
P. ayam (0) & 3.57 & 0.50 & $3.32 \mathrm{bcd}$ \\
P. sapi (10) & 3.49 & 0.51 & $2.97 \mathrm{~d}$ \\
P. sapi (0) & 3.72 & 0.55 & $3.59 \mathrm{ab}$ \\
P. kambing (10) & 3.78 & 0.51 & $3.65 \mathrm{ab}$ \\
P. kambing (0) & 3.61 & 0.49 & $3.13 \mathrm{~cd}$ \\
Tanpa pupuk & 3.67 & $0.52 \mathrm{xy}$ & $3.40 \mathrm{y}$ \\
\hline Rata-rata & 3.52 & 0.43 & 3.22 \\
\hline P. ayam/sapi/kambing (10) & 3.26 & 0.36 & 2.66 \\
\hline Konvensional & & & \\
\hline
\end{tabular}

Keterangan: Angka yang diikuti huruf kecil yang sama tidak menunjukkan perbedaan yang nyata pada taraf $5 \%$. Huruf $\mathrm{x}$ artinya berbeda nyata pada uji $t$ dengan perlakuan pembanding pupuk kandang ayam/sapi/kambing tanpa residu tanaman. Huruf y artinya berbeda nyata pada uji $t$ dengan perlakuan pembanding konvensional 
Pengaruh Pengurangan Dosis Pupuk Kandang dan Penambahan Residu Tanaman terhadap Kadar Hara NPK pada Jaringan Tanaman Sawi Hijau

Jenis residu tanaman jagung dan kedelai yang diaplikasikan untuk tanaman sawi tidak berpengaruh terhadap kadar hara NPK di jaringan tanaman (Tabel 5). Penggunaan berbagai kombinasi jenis dan dosis pupuk kandang juga tidak berpengaruh terhadap kadar $\mathrm{N}$ dan $\mathrm{P}$ pada tanaman sawi, namun nyata pada K. Pemberian pupuk kandang ayam sebanyak 10 ton ha ${ }^{-1}$ memberikan kadar hara $\mathrm{K}$ tertinggi pada jaringan tanaman. Hal ini didukung oleh tingginya sumbangan hara K dari pupuk tersebut (Tabel 4). Penelitian Silahooy (2008) menunjukkan bahwa peningkatan dosis pupuk $\mathrm{K}$ berbanding lurus terhadap serapan $\mathrm{K}$ pada kacang tanah. Jumlah $\mathrm{K}$ yang diserap tanaman ditentukan oleh beberapa faktor, salah satunya adalah konsentrasi kalium, sehingga ketersediaan $\mathrm{K}$ yang cukup tinggi di tanah akan meningkatkan serapannya pada tanaman.

Tidak ada perbedaan nyata antara pengaruh penambahan masing-masing jenis pupuk kandang (10 ton $\mathrm{ha}^{-1}$ ) dan tanpa penambahan pupuk kandang terhadap kadar hara $\mathrm{K}$ pada jaringan tanaman. Hal ini menunjukkan bahwa sumbangan hara yang diberikan oleh residu ketiga jenis pupuk kandang tersebut pada MT 1 telah mencukupi kebutuhan hara tanaman hingga MT 2. Jika dibandingkan ketiga jenis pupuk tersebut, penggunaan pupuk kandang sapi yang hanya dilakukan pada musim tanam pertama memberikan hasil terendah pada kadar $\mathrm{K}$ di jaringan tanaman.
Angka kecukupan hara tanaman pada percobaan ini telah tercapai, sehingga kadar $\mathrm{N}$ dan $\mathrm{P}$ jaringan tanaman tidak berbeda nyata pada berbagai jenis residu tanaman, jenis serta dosis pupuk kandang. Menurut IFA (1992), angka kecukupan hara NPK pada jaringan daun Brassica oleraceae berturut-turut, yaitu 3.3, 0.5, dan 3.1\%.

\section{Pengaruh Pengurangan Dosis Pupuk Kandang dan Penambahan Residu Tanaman terhadap Penyerapan Hara Tanaman Sawi Hijau}

Status hara tanah dapat menunjukkan suplai hara yang dibutuhkan tanaman untuk memberikan produksi yang maksimal (Mandal dan Chattopadhyay, 2015). Jenis residu tanaman tidak berpengaruh terhadap penyerapan hara NPK tanaman sawi hijau (Tabel 6). Penggunaan kombinasi jenis dan dosis pupuk kandang juga tidak memberikan pengaruh terhadap serapan hara N. Penggunaan pupuk kandang kambing menunjukkan serapan hara $\mathrm{P}$ dan $\mathrm{K}$ tertinggi pada tanaman sawi. Serapan hara K masih cukup tinggi pada penambahan dan tanpa penambahan dosis pupuk kandang ayam dan kambing, walaupun tidak berbeda nyata. Hal ini disebabkan oleh sumbangan hara $\mathrm{P}$ dan $\mathrm{K}$ yang tinggi pada kedua pupuk kandang tersebut (Tabel 4). Sumbangan hara yang tinggi akan menyebabkan penyerapan hara tanaman juga lebih tinggi. Hal ini sesuai dengan penelitian Ispandi dan Munip (2004) yang menunjukkan bahwa pemupukan $\mathrm{K}$ dapat meningkatkan $\mathrm{K}$ tersedia di tanah, sehingga dapat diserap oleh tanaman.

Tabel 6. Pengaruh residu tanaman dan jenis serta dosis pupuk kandang terhadap serapan hara tanaman sawi

\begin{tabular}{|c|c|c|c|}
\hline \multirow{2}{*}{ Perlakuan } & $\mathrm{N}$ & $\mathrm{P}$ & $\mathrm{K}$ \\
\hline & \multicolumn{3}{|c|}{$\ldots \ldots \ldots \ldots \ldots \ldots \ldots \ldots \ldots\left(\mathrm{kg} \mathrm{ha}^{-1}\right) \ldots \ldots \ldots \ldots \ldots \ldots \ldots \ldots$} \\
\hline \multicolumn{4}{|l|}{ Jenis residu } \\
\hline Kedelai & 77.15 & 10.58 & 69.76 \\
\hline Jagung & 59.46 & 8.79 & 56.68 \\
\hline \multicolumn{4}{|c|}{ Jenis dan dosis pupuk kandang (ton $\mathrm{ha}^{-1}$ ) } \\
\hline P. ayam (10) & 80.52 & $11.25 \mathrm{ab}$ & $75.87 \mathrm{ab}$ \\
\hline P. ayam $(0)$ & 67.72 & $9.55 \mathrm{ab}$ & $61.71 \mathrm{ab}$ \\
\hline P. sapi (10) & 68.52 & $9.74 \mathrm{ab}$ & $64.09 \mathrm{ab}$ \\
\hline P. sapi (0) & 54.09 & $8.47 \mathrm{ab}$ & $46.68 b$ \\
\hline P. kambing (10) & 90.95 & $13.50 \mathrm{a}$ & $89.20 \mathrm{a}$ \\
\hline P. kambing (0) & 64.04 & $8.28 \mathrm{ab}$ & $60.69 \mathrm{ab}$ \\
\hline Tanpa pupuk & 52.31 & $7.02 \mathrm{~b}$ & $44.33 b$ \\
\hline Rata-rata & $68.31 x y$ & $9.68 x y$ & $63.22 x$ \\
\hline P. ayam/sapi/kambing (10) & 38.06 & 4.6 & 34.58 \\
\hline Konvensional & 36.75 & 4.23 & 30.96 \\
\hline
\end{tabular}

Keterangan: Angka yang diikuti huruf kecil yang sama tidak menunjukkan perbedaan yang nyata pada taraf 5\%. Huruf $\mathrm{x}$ artinya berbeda nyata pada uji $t$ dengan perlakuan pembanding pupuk kandang ayam/sapi/kambing tanpa residu tanaman. Huruf y artinya berbeda nyata pada uji t dengan perlakuan pembanding konvensional 
Pengaruh Teknik Budidaya terhadap Pertumbuhan dan Hasil Tanaman Sawi Hijau

Tanaman sawi yang dibudidayakan dengan teknik yang berbeda memberikan pengaruh yang nyata terhadap pertumbuhan dan produksinya. Hal ini dapat dilihat dari hasil uji $\mathrm{t}$ dengan perlakuan pembanding tanpa menggunakan residu tanaman dan secara konvensional (Tabel 2 dan 3). Aplikasi residu tanaman pada sistem rotasi tanaman menghasilkan pertumbuhan dan hasil yang lebih baik jika dibandingkan dengan budidaya secara organik tanpa penambahan residu tanaman dan konvensional. Hal ini disebabkan oleh perlakuan penambahan residu tanaman pada pemupukan organik memiliki sumbangan hara tertinggi (Tabel 4). Menurut Adiku et al. (2008), penambahan residu akan meningkatkan karbon organik tanah. Kondisi ini mampu menahan air tanah, sehingga aktivitas mikroba tanah juga meningkat akibat adanya mineralisasi karbon.

Budidaya sawi organik yang hanya mengandalkan pupuk kandang tanpa residu tanaman memberikan bobot sawi per hektar yang lebih tinggi jika dibandingakan dengan budidaya secara konvensional (Tabel 3). Hal ini disebabkan oleh sumbangan hara dari pupuk kimia yang digunakan lebih rendah daripada pupuk kandang yang digunakan (Tabel 4).

Sumbangan hara NPK di tanah dengan pemberian pupuk kandang setelah pemberian residu tanaman rata-rata meningkat berturut-turut sebesar 65.7, 6.01, dan 50\% jika dibandingkan dengan pupuk kandang tanpa residu tanaman (Tabel 4). Peningkatan kandungan hara akan meningkatkan pertumbuhan dan produksi tanamanan sawi (Tabel 2 dan 3). Hal ini didukung oleh hasil penelitian Islami (2012) yang menuliskan bahwa perlakuan residu bahan organik menunjukkan pertumbuhan yang lebih baik dibandingkan perlakuan non residu bahan organik. Padmini et al. (2008) juga menambahkan bahwa bahan organik berperan meningkatkan kapasitas tukar kation dan kapasitas tukar anion.

Budidaya sawi organik dengan penambahan residu tanaman juga memberikan pengaruh terbaik terhadap kadar $\mathrm{P}$ dan $\mathrm{K}$ pada tanaman (Tabel 5). Hal ini disebabkan oleh perbedaan yang sangat jelas ditunjukkan oleh sumbangan hara $\mathrm{K}$ pada Tabel 4, walaupun perbedaan sumbangan hara $P$ pada perlakuan aplikasi residu tanaman dan tanpa residu tanaman sangat kecil. Hal ini diduga oleh ketersediaan hara $\mathrm{P}$ akan lebih maksimal jika jumlah bahan organik yang digunakan juga lebih banyak karena dapat meningkatkan aktivitas mikroorganisme dalam menyediakan hara potensial di tanah.

Perbedaan kadar hara $\mathrm{K}$ pada tanaman sawi yang dibudidayakan secara organik dengan penambahan residu tanaman dan konvensional juga dipengaruhi oleh tingginya kandungan $\mathrm{P}$ pada pupuk kandang yang digunakan. Berdasarkan penelitian Ispandi dan Munip (2004), hara K diserap tanaman melalui proses difusi yang memerlukan banyak energi ATP. Tingginya hara $\mathrm{P}$ pada pemupukan organik dapat meningkatkan serapan P yang secara langsung dapat meningkatkan pembentukan ATP, sehingga serapan hara $\mathrm{K}$ juga meningkat.

\section{KESIMPULAN}

Penggunaan residu tanaman kedelai dan jagung dapat dilakukan pada budidaya sawi hijau di musim tanam kedua sebagai tambahan unsur hara. Penggunaan pupuk kandang ayam dan kambing memberikan bobot segar per tanaman yang lebih tinggi, namun persentase tanaman yang dihasilkan lebih rendah dibandingkan dengan pupuk kandang sapi. Pengurangan dosis pupuk kandang dapat dilakukan pada MT 2 jika pada MT 1 diberikan pupuk kandang sebesar 20 ton $\mathrm{ha}^{-1}$ dan pengembalian residu tanaman dari MT 1 .

\section{DAFTAR PUSTAKA}

Abbasi, M.K., M.M. Tahir, N. Sabir, M. Khursid. 2015. Impact of the addition of different plant residues on nitrogen mineralization-immobilization turnover and carbon content of soil incubated under laboratory conditions. Solid Earth 6:197-205.

Adiku, S.G.K., S. Narh, J.W. Jones, K.B. Laryea, G.N. Dawuona. 2008. Short-term effects of crop rotation, residue management, and soil water on carbon mineralization in a tropical cropping system. Plant and Soil 311:29-38.

Agustina, L., R. Intan, Koestiharti, U. Khumairoh. 2012. intercropping sweet corn (Zea mays Saccharata Sturt) and pakchoy (Brassica juncea) in the different organic matter compositions. J. Agric. Food. Tech. 2:35-40.

Blair, N., R.D Faulkner, A.R Till, G.J Crocker. 2006. Longterm management impacts on soil $\mathrm{C}, \mathrm{N}$, and physical fertility part III: Tamworth crop rotation experiment. Soil Tillage Res. 20:48-56.

[IFA] International Fertlizer Industry Association. 1992. IFA World Fertilizer Use Manual. IFA Press. Limburgerhof, Germany.

Islami, T. 2012. Pengaruh residu bahan organik pada tanaman jagung sebagai tanaman sela dan pertanaman ubi kayu. Buana Sains 12:131-136.

Ispandi, A., A. Munip. 2004. Efektivitas pupuk PK dan frekuensi pemberian pupuk $\mathrm{K}$ dalam meningkatkan serapan hara dan produksi kacang tanah di lahan kering Alfisol. Ilmu Pertanian 11:11-24.

Kresnatita, S., Koesriharti, M. Santoso. 2013. Pengaruh rabuk organik terhadap pertumbuhan dan hasil tanaman jagung manis. Indonesian Green Technol. J. 2:8-17.

Liang, Y., C. Bai, L. Mu, M. Zhou. 2014. Soil respiration in cucumber field under crop rotation in solar greenhouse. Sci. Agric. 71:337-341. 
Mandal, D.,G.N. Chattopadhyay. 2015. Balanced nutrient management of mustard (Brassica juncea L.) in ricemustard- sesame cropping system in red and lateritic soil. Int. J. Plant Animal Environ. Sci. 5:224231.

Mohammad, W., S.M. Shah, S. Shehzadi, S.A. Shah. 2012. Effect of tillage, rotation, and crop residues on wheat crop productivity, fertilizer nitrogen and water use efficiency and soil organic carbon status in dry area (rainfed) of North-West Pakistan. J. Soil Sci. Plant Nutr. 12:715-727.

Oryschak, M., D. Chrapko, N.H. Rawlins, S. Jones, C. Korth, L. Kryzanowski, J. Neden, D. Pauly, K. Tremblett, T. Wallace. 2011. Nutrient Management Planning Guide. Alberta Agriculture Food Publ. Edmonton, Canada.

Padmini, O.S., Tohari, Prajitno, D. Syukur. 2008. Kombinasi pupuk organik-NPK dalam rotasi tanaman berbasis padi untuk peningkatan sifat kimia tanah dan hasil padi. Ilmu Pertanian 15:59-68.

Rahman, M.M., M.S. Azirun, A.N. Boyce. 2013. Response of nitrogen fertilizer and legumes residues on biomass production and utilization in rice-legumes rotation. J. Animal Plant Sci. 23:589-595.
Ramadhani, E. 2011. Kajian aplikasi jenis pupuk untuk produksi dua varietas kedelai secara organik dengan sistem budidaya jenuh air pada dua musim tanam. Tesis. Institut Pertanian Bogor. Bogor.

Silahooy, C. 2008. Efek pupuk KCl dan SP-36 terhadap Kalium tersedia, serapan Kalium dan hasil kacang tanah (Arachis hypogaea L.) pada tanah Brunizem. Bul. Agron. 36:126-132.

Supriyadi, S. 2008. Kandungan bahan organik sebagai dasar pengelolaan tanah di lahan kering Madura. Embryo 5:176-183.

Susanto, R. 2002. Penerapan pertanian organik. Kanisius, Yogyakarta.

Trisnadewi, A.A.A.S., T.G.O. Susila., I.W. Wijana. 2012. Pengaruh jenis dan dosis pupuk kandang terhadap pertumbuhan dan produksi jagung manis. Pastura $1: 52-55$.

Yulia, A.E., Murniati, Fatimah. 2011. Aplikasi pupuk organik pada tanaman caisim untuk dua kali penanaman. Sagu 10:14-19. 